\title{
Analysing Males in Africa: Certain Useful Elements in Considering Ruling Masculinities
}

\author{
Kopano Ratele \\ Professor, Institute for Social and Health Sciences and Centre for Peace Action, \\ University of South Africa, PO Box 1087, Lenasia, 1820, \\ South Africa, Fax +27118571770 \\ ratelk@unisa.ac.za
}

\begin{abstract}
This article examines the questions why and how African males have been analysed, informed by the view that across several societies in Africa undeclared yet public gender wars of words and deeds go on daily, and may even be intensifying. It argues that though interventions with males from feminist perspectives have gained ground over the last few decades, more radical, to the gendered African worlds and masculinities have failed to materialise because analyses of boys and men's lives have tended to be blind to the imbrications of the experience of maleness with the experience of other significant social categorisations, such as being without gainful employment. Consequently, many interventions, such as those around violence against women and girls, have failed to grasp some of the critical factors underlying males' reluctance to support feminist action. The article therefore routes its examination of males through a number of categories of social-psychological experience and practice, namely (a) occupational and income attainment and, (b) age, categories theoretically tied to maleness and to practices geared towards the attainment of ruling masculinity. The article reveals the manner in which the psychosocial and the political inter-penetrate each other in the lives of African males. In conclusion, the recognition of the heterogeneous nature of masculinities also, ironically, affords mounting new feminist interventions into changing traditional ruling ideas of being a man or boy.
\end{abstract}

\section{Keywords}

African males, age, income, masculinities, psychopolitics

\section{Introduction}

In several African societies, traumatic acts of violence against women and girls go on daily - such that they may be referred to as part of undeclared yet public gender wars. In Manzini, Swaziland, for example, a young woman supposedly angered bus conductors so much by wearing a miniskirt that they stripped and gang-raped her at the bus terminus while spectators cheered them on 
(IRIN/UN Office for the Coordination of Humanitarian Affairs, 2005). Similarly, in nearby South Africa the media reported that a young woman was attacked by male taxi industry workers at a taxi rank in Johannesburg city for wearing a miniskirt (e.g., SAPA, 2008). Her clothes were ripped off her body, others went for her underwear, and even though she held on tightly to her panties which were torn in the process, some of the people (whose sex was unspecified in the news-report) inserted their fingers in her vagina. Out of Darfur, the Sudan, Women's News Network (2008, unpaginated) conveyed a report on how "Janjaweed militia kidnapped a 12-year-old girl and gang-raped her for a week, pulling her legs so far apart that she was crippled for life." The report further observed that besides being sexually violated, another big fear of Sudanese women is that they will never find a husband because in Sudan's law raped women can be prosecuted for adultery or fornication.

How are we to understand such violence without paralysing ourselves by the wholesale condemnation of all males, yet without psychologising every act of male violence? While it does not focus on gender-based violence per se, this article seeks to show how to think of males as a group whose actions against and domination of females is structurally supported, without encouraging a wilful neglect of the conditions of males, who in their personal stations find themselves subordinate to those who are in ruling positions in society. In addition, the article also looks at other reasons why and how males have been studied.

One of the tools that have been used to analyse such violence and other male practices is that of "hegemonic masculinity," the influence of which within studies of gendered male lives and power is well-established. Not only is this sociological concept pervasive in Australian, European and NorthAmerican research but its reach extends into the heart of studies of boys and men in Africa, Asia, Latin America, and the global South generally (e.g., see Adomako Ampofo \& Boateng, 2007; Barker, 2005; Dolan, 2002; Lindsay \& Miescher, 2003; Nilan, Donaldson, \& Howson, 2007; Ouzgane \& Morrell, 2005; Ratele, Fouten, Shefer, Strebel, Shabalala \& Buikema, 2007; Vijayan, 2002). What the originating group of researchers aimed to render with the concept of hegemonic masculinity were those things that allow women's social subordination to men to continue (Carrigan, Connell \& Lee, 1985). Hegemonic masculinity is, in other words, a mesh of social practices productive of gender-based hierarchies, including violence that supports these hierarchies; that is, the unequal relations between females and males as groups.

From the body of literature and conferences that the concept of hegemonic masculinity continues to generate, it has been a way of talking about males that clearly finds resonance across many countries, in a variety of settings and disciplines. Along with the notion of masculinity, the concept of hegemonic 
masculinity has generally served us well in bringing to attention, following feminist thought, the understanding of manhood (as opposed to maleness) as a social practice that manifests in many forms (such that we now speak of masculinities). However, there is much to be gained in recovering an analysis of male practices and experiences grounded in social conditions as well as those things to be found in the psychosocial realities of individual males. Grounding itself on this terrain, this article argues that masculinities are better seen as created at both the social and psychological levels, something males do and establish in ongoing activity in relation to females, to other males, but also in relation to their own inner lives. It is on this ground where one of the most troubling questions confronts researchers of male lives: how to analyse males who are powerless in relation to other males but at the same time members of a powerful gender group in relation to females. Obviously pertinent to other fields of study of inter-group power relations, this question is especially germane for researchers in societies geographically outside of the high income, highly industrialised world - a distinction which does not, of course, indicate that living in low income countries necessarily implies subjects are symbolically outside the globalised circulation of images and goods, unaffected by the effects of world trade and financial markets (see Castells, 2000).

While it examines some of the work on males in Africa, the article does not review the literature as much as it seeks to point to a number of aspects regarding the question why and how males have been investigated as subjects of gender. The article suggests that some of the work on male gender power (including work on men's violence against women), that tends to remain blind to the imbrication of the experienced realities of a boy or man with the experience of other significant social-psychological categorisations, such as being without gainful employment (however, see Field, 2001; Langa and Eagle, 2008) leads to a failure to fully understand the intricacies that riddle the lives of African males. As a consequence, such work also fails to grasp some of the factors underlying male-on-female violence, male violence towards other males, and the factors underlying many males' contrariness or indifference to feminist action around social issues. To be sure, disregard of the intersection of gender and poverty/unemployment in male lives haunts not just gender studies; it also trouble studies of poverty and of development, for example (e.g., African National Congress, 1994; United Nations Development Programme South Africa, 2003). In sum, most studies on gender fail to look closely into how the effects of little or no income for males interacts with other psychosocial experiences, and in turn flows into burdens of masculinity, prompting violent reactions against women's independence and feminism. Hence, this article routes the examination of males through a number of categories of 
social-psychological experience and practice. The categories selected for analysis here are limited by concerns of space and are not exhaustive, chosen because they are some of those that have either received less attention but appear to have wide resonance in daily life or, where they have been noted in studies of African men and boys (e.g., Miescher, 2007) they require penetrating by psychopolitical analyses - by which is meant analyses of the individual experience in an overtly socio-political terms and of socio-political developments with the vocabulary of psychology (Hook, 2004). The categories of experience and practice chosen for this article are: (a) occupational and income attainment and, (b) age. These categories are then read with the help of the conceptual lens of masculinity.

The article begins by elaborating the need and justification for studies of males in Africa from the perspective of masculinity as well as some of the criticism of the concept of masculinity generally, and hegemonic masculinity specifically. It then turns to the categories of social-psychological practice and experience selected for consideration, and in unpacking each of them show the complexities that need considering in how African males are approached. These complexities, the article shows, arise out of and in turn result in the fracturing of the group "African males".

\section{The "Turn to Masculinity" in Gender work and some Problems with Masculinity}

Forms of violence against women and girls by males as well as legislation and cultures which shore up such violence as exemplified above, are one set of justifications that have been advanced for the "turn to males and masculinity" in interventions and analyses of gender power and sexual violence 1980s (also see, e.g., Brod, 1987; Journal of Southern African Studies, 1998; Kimmel, Hearn \& Connell, 2005; Mac an Ghaill, 1996; Morrell, 2001; Ouzgane \& Morrell, 2005; Reid \& Walker, 2005; Ruxton, 2004; Women's Commission for Refugee Women and Children, 2005; United Nations Division for the Advancement of Women/Joint United Nations Programme on HIV/Aids/ International Labour Organisation/United Nations Development Programme, 2004; United Nations International Research and Training Institute for the Advancement of Women (INSTRAW), no date; United Nations Population Fund, 2005). For instance, INSTRAW (no date) addresses itself to such experiences of traumas females are subjected to by males when it argues that "men are central to most acts of violence, and violence is central to being a man in many cultures" (unpaginated). On this basis, and given the fact that "most political, cultural and religious leaders around the world - those in better posi- 
tions to influence change - are also men" it is vital to engage "men to end gender-based violence" (INSTRAW, no date, unpaginated).

The texts referred to above go some way to invalidate rationalizations of male practices and masculinity that are keen to concentrate on evolution, mythical traditions, hard-wiring, genes or hormones and not so much on confronting violent practices (see, e.g., Bly, 1990; Dobson, 2002). Dobson (2002) has, for instance, called the idea that sexism and patriarchal cultural biases play a part in the way children are bred into boyhood and girlhood "goofy" and "dangerous". He says that the different hard-wiring of the brains and the hormones of males and females, whose influence "feminists attempted to suppress or discredit but failed", are what "accounts for behavioral and attitudinal characteristics traditionally associated with masculinity and femininity" (2627). Research has shown, though, that "there are direct links between violence and conflict with the way that manhoods or masculinities are constructed" (Barker and Ricardo, 2005: 24). And overtly or unseen, manifesting bodily, economically, politically, culturally or in other forms, violence and its threat are key mechanisms underlying certain kinds of masculinity and femininity, and male group power over females (Breckenridge, 1998; Hearn, 1987; Kimmel, 1987).

Another set of reasons for considering males in projects on violence against women (and from the perspective of gender studies generally) extends the last but runs along the lines followed by, among others, Cleaver (2002: 2-5), where she delineates the arguments for including men (see also, Adomako Ampofo \& Boateng, 2007; UNPFA, 2005). In addition to the harm that certain attitudes and behaviours of males bring upon females and other males, work with males is argued for as enabling us to minimise "problems brought by the excesses of masculinity (and) harmful concepts of masculinity" (Adomako Ampofo \& Boateng (2007: 71). The UNPFA similarly contends that work on gender equality and violence against women would benefit from the support and involvement of males since "men themselves are increasingly challenging notions of "masculinity" that restrict their humanity, limit their participation in the lives of their children, and put themselves and their partners at risk" (2005:5). Many men, argues the UNPFA, "want to become more supportive husbands and fathers, but need support to overcome deeply entrenched ideas about gender relations.... Stronger efforts to involve men more fully in reproductive health, family life and gender equality are urgently needed" (2005: 4-5).

Whether or not some, many or most men do in fact want to change is a question that needs more theoretical and empirical investigation. All the same, pro-feminist work on boys and men, within which this article is located, 
moves from the premise that males must be mobilised to change and challenge structures and practices that support oppressive masculinities and gender inequity. As such studies which employ the concepts of gender and masculinity in a critical fashion to think of males see themselves as part of activities within a loose global movement to support gender justice, that is, to advance the full participation of females in male-dominated societies. Indeed, the principal aim that ties the different studies under the eclectic framework of critical studies on African boys and men is to understand the gender of male lives and the impact of different masculinities on males and females (e.g., Agenda, 1998; Gibson \& Hardan, 2005; Morrell, 2001; Shefer, Ratele, Strebel, Shabalala \& Buikema, 2007). In this respect, Corrigan, Connell and Lee (1985: 15) have argued that "the political meaning of writing about masculinity turns mainly on its treatment of power". And, introducing the collection of studies in "From boys to men" by Shefer and her associates, Connell reiterates the fact that feminist work and the women's liberation movement have "conclusively shown the massive patterns of gender equality that mark the contemporary world so conclusively that the issue can only be ignored by those who wilfully close their eyes to massive social injustice," therefore, "men, as the principal holders of power in modern gender orders, are in an important sense "gatekeepers for reform" (2007: ix). Consequently, to reach that world where females and males are treated without prejudice in all areas of all life affecting them, studies of men and masculinities argue that change among males has to happen. In the same way, studies of African males and masculinities can only be unjustifiably blind and thus perpetuate the violent oppression of females if they choose not to be informed by, and aligned with, feminism and women's movements.

Nonetheless, there have been numerous problems with the notion of hegemonic masculinity, including certain shortcomings, confusion or lack of clarity. One of the troubles with the way the notion is used is that it often collapses males onto masculinities - that is, being of the sex one has already achieved masculinity. Here then there is a space to insert a point about the use of the terms males and females, alongside those of boys, girls, men and women. While the terms boys and men, girls and women and masculinity/masculinities are key as far as how they surface the gendering of male subjects, that is to say, how male bodies and psyches are socially masculinised, often it is important to use the terms males and females, as is done here, since they, in contrast, point to the social process of a yet-to-be-made man or boy. Males are not by nature men. It is in families, most times, that the processes of turning babies into boys and boys into men is usually begun; families which, with the help of available knowledge and power, saturate the bodies, psyches, desires, and daily practices of youngsters with images of and ideas about masculinity. 
A problem related to that above is noted by Jeff Hearn (1996) who argues that it is more productive to study 'what men do or think or feel' than talk about masculinity (1996: 214). Similarly, Kenneth Clatterbaugh says that the terms masculinity and hegemonic masculinity "carry a lot of historical baggage, which unless great care is exercised in their use, leads to confusion and careless thinking" (1998: 25). Clatterbaugh was troubled by the replacement of the terms men by the terms masculinity/masculinities as well as, specifically, hegemonic masculinity/masculinities in gender studies. "Talking about masculinities, simpliciter and unexplicated," he observed, "simply imposes a layer, a very confused layer, between ourselves and the social reality that we want to discuss" (1998: 42). That reality is the body of facts in societies, in the form of institutions, traditions and contexts such as families, schools, workplaces, the media, and religious establishments, which generate and uphold the domination of males as a group over females as group.

Yet another problem is that along the way the term masculinity has accreted negative overtones. Interestingly, this occurs among critical citizens as well. Even though analyses have shown that there are multiple, fluid forms of masculinity (Connell, 2005), there is a tendency to deploy the term as if it is a synonym for trunk-sized biceps, deep voice, gun in hand, laddish habits, unflagging sexual stamina or a more or less similar set of traits or unchanging behaviours.

Important as it is to challenge men with guns, or the pressures males are subjected to or subject themselves to in respect to their bodies, behaviours or habits, it is as vital to dispel this stereotype of masculinity. There are selfevident, significant differences born out of history and cultures between African males and masculinities and Asian, European, South American or North American males and masculinities that need observing when analysing male lives. But there are also crucial variations within the male group and amongst different forms of masculinities in Africa. The multiplicity of masculinities is not only due to the fact that beside the ruling ideas of being a man to be found in any one place there are always likely to be dominant, subordinate and complicit masculinities (Connell, 1995; Ratele, 2006). It is also because there is considerable purchase in thinking of males as gendered subjects as well as subjects of ethnicity (Luo vs Kikuyu, black South African language speakers vs black language speakers from other African countries), race (white vs black), and political choice (supporter of Robert Mugabe vs supporter of Morgan Tsvangirai, supporter of Thabo Mbeki vs supporter of Jacob Zuma) - among other social-psychological categorisations. It seems clear that within each of these categorisations we are likely to find dominant, subordinate and complicit masculinities. The fact then is that African males are a very heterogeneous 
group, African masculinities plural, and being a man or boy is quite often internally inconsistent. Accounting for the intersections and distinctions makes it possible to evade treating males as a homogeneous group and turning masculinity into a negative, unchanging set of traits. Indeed, what some theorists have sought to clarify is that what is at issue in studying men or boys are not traits or essences but sets of male practices in relation to themselves, to other males and to females. Studies of African males that do not address their positioning in society as well as their cognitions, emotions and bodily practices are likely to perpetuate stereotypes, misunderstand and delay efforts towards democratising gender relations. In researching and mobilising males, activists and scholars need to consider male personal biographies, including their fantasy lives, as well as conditions of societies, such as levels of employment and violence.

Critiques such as those noted above prompted Connell and Messerschmidt, (2005) to re-examine the tenets of the idea of hegemonic masculinity. In their review of the history, use and critique of the idea the authors arrive at the conclusion that some aspects about the concept are supported by research findings and theoretical analyses and need to be retained, others can be rejected, while some others could use reformulation. They argue that among the aspects that ought to be retained (and whose utility becomes even more evident below), are the plurality of masculinities, their hierarchical arrangement, their institutionalisation and the possibility for change. They also maintain that it is through cultural consent rather than always simple forceful domination that masculinities become effective. Among those aspects that the concept needs to be evacuated of, which we dealt with already but more later, are a simple, global pattern of men's domination of women as well as masculinity as a fixed character type or set of traits. And last, what needs rethinking, are, among other things, the local, specific, geographic, regional coordinates that must be factored in thinking of the making of masculinity, the ways in which men use and inhabit their bodies. A consideration of the intersections of age and employment and income on one side, and maleness on the other, as we shall now turn to, is precisely an attempt to ground analysis of male practices and experiences and the making of masculinity in local, specific African conditions given the persisting unequal North-South relations.

\section{Age and African Manhood}

The main question that needs asking in relation to age, as in relation to other categories that organise and fragment individual and group life is: what do studies employing the lens of masculinity tell us about individual African 
males who are socially positioned as dominant but find that in their personal lives they are non-dominant vis-à-vis other males? This question is similar to one asked by that Gary Barker in reference to males in Brazil, the United States of America, Nigeria and the Caribbean. "I have been asking young men", he writes, "to reflect on the question: 'Self, how did I get here?' How did I get to be this kind of man? How did I acquire this particular gendered identity?" (2005: 25). The main difference is that in this article the self, or the experiencing or practicing male, is considered as simultaneously located within, and better understood from, both the registers of the psychological and the political. This insight about the psychological as saturated with politics, and politics as profitably open to psychological interpretations, is owed to, amongst others, the works of the South African political activist Stephen Biko (1978), the psychologist Noel Chabani Manganyi $(1973,1991)$, and the psychiatrist Frantz Fanon (1986, 1990). Using these and others, Hook (2004) has argued for accounting for both psychological and political facts and "their reciprocal and combined effects" in thinking of life in the postcolonies. "Crucially, one should understand, first, how politics impacts upon the psychological. More than this, though, one should similarly attempt to understand how personal psychology might repeat, internalise and further entrench such political effects at the level of personal identity (Hook, 2004: 90).

The question being asked of, for instance, a young unemployed man in Ethiopia or Rwanda, therefore is, 'What are the spatio-temporal conditions and what is it in me that have made me to be the man I am?' Posed thus, the question locates males in relation not only to what happens internally, in how they identify in the boyhood or manhood they inhabit and deploy, but also pushes us to see their desires in relation to others, to other males and females, disciplined by the economic and political order, subject to social and cultural organisation. An understanding of the relationality of the construction of males as gendered subjects, keeping the idea psychopolitics in mind, is therefore an invitation to appreciate that males' understanding of masculinity is co-dependent on kith and kin, on interactions with sexual and marital partners, exchanges with workmates, bosses, juniors, playmates, others, all such interactions being themselves positioned in society in particular ways. What such an appreciation further does is expose the relevance of politically-aware psychological studies of males in Africa from a gender perspective to a whole host of other issues pertinent to many African countries (Connell \& Messerschmidt, 2005, p. 846). This understanding in place, consider now how age intersects with masculinity for African males.

The least difficult route for any male to achieve successful masculinity in much of the world is to be dominant over females and other males. This sounds like a tautology in that masculinity is definable by the socially dominant 
position of males over others (Corrigan, Connell \& Lee, 1985). However, what it encapsulates is that the possession of a penis needs to always be held separately from the achievement of masculinity, and more so from the cherished masculinity in a particular place. Since maleness and masculinity are different things it makes sense that males have to engage in certain activities, learn to speak in particular ways, avoid certain topics and occupy a certain station in society to be regarded as successfully masculine. The activities that go towards producing or supporting masculinity include such things as working outside the home, avoiding subjects such as baby-feeding in conversation, and occupying positions of leadership, overseer, manager and crucially, "official" head of household (Adomako Ampofo \& Boateng, 2007; Hunter, 2005; Sideris, 2005). Therefore, the successful domination of males over females is attainable through a number of routes, some of these being relatively easier to travel than others, and the easiest of them all being that traveled with the ticket of age. Put differently, the simplest of all ways to becoming a man is through reaching a certain age. Researchers have made note of the fact that "age and seniority are important to the organization of gender in Africa (Miescher, 2007: 254). Amongst the interesting implications about age and seniority in relation to manliness is that in the pre-colonial period or outside of colonial reach, post-menopausal females and females who "occupied male stools or chiefly offices", as Miescher has observed in his study in southern Ghana's Akan societies, could become "ritual men", "embodying a form of "female masculinity," attaining social positions reserved for men". Also, "men and women's gender positions [could] change in the course of their lives... [since] old age blurred the lines of gender politics" (2007: 254).

The general point to underline as far as masculinity is concerned is that age positions males in specific bio-psycho-cultural ways and hence differentiates within and between genders. That is to say, in certain traditions, when a male gets to a certain age, he is permitted to undergo the rites of passage, such as ulwaluko among amaXhosa and lebollo among Basotho (see Gqola, 2007), which if successfully completed, repositions him bio-psycho-culturally; from then on, others within the culture are required to relate to him differently - as a man and not a boy.

Given that one cannot do much about when one is born (even though age can be falsified) or when one dies (although one can sometimes choose suicide), the relationship of age and manhood is an odd one in the calculus of gender domination. The most interesting aspect of this relationship is that one part contributing to male domination is a relatively active achievement (masculinity) while the other (age) is passive. While masculinity provokes males to do certain things in order to be a man, that is, a male cannot do much but wait 
until he reaches the age where society permits him to vote, attend initiation school, gain employment, drive or marry. Here then a productive avenue of analyzing and mobilising African males opens up. The avenue appears from the combination of passive and active elements in masculinity. This combination indicates how males are both positioned and position themselves in becoming boys and men. On the one hand, males cannot but be acted upon by outside economic, political and cultural forces; on the other, they actively manage their inner selves and work at their relations with the external world. Studies support this idea of a combination, of males being positioned by norms and regulations, and positioning themselves consciously and unconsciously, in constructing their masculine identities. For example, in their study Blackbeard and Lindegger (2007: 42) conclude that the subject position of the boys they studied:

were situated as multivocal, 'psycho-discursive acts' in contexts that were defined in real and imagined space and in relation to imaginary sets of norms and audiences, such as the male peer group... This suggests that, in terms of the subjectivity of masculine identity, masculinities were constructed through multiple and contradictory self-narratives, consciously and unconsciously..."

That realities and fantasies, fabrications and normative regulations are co-constituents of masculinity further reinforces and is reinforced by the view that there are a number of masculinities available in a particular culture, country, or continent. Masculinity is in fact neither a uniform, homogenous thing nor an infinite, original set of objects. It is rather "always ready made, always social first and personal second" (Wetherell and Edley, 1999: 342), limited and coloured by social-psychological realities and "fictions". The achievement of masculinity involves distinct procedures by males for "imaginary positioning" and "the production of a self" in relation to what it means to be a man; and the production of self in turn "involves investment where there is a coincidence between self and some masculine persona" (343).

We should be clear that masculinities are unlike age-cohorts, such that one can tell from counting the cohorts how many masculinities are represented amongst males in a specific country, ethnic group, school or family. "There are no ready criteria that allow one to identify distinct masculinities" (Clatterbaugh, 1998: 27), precisely because in how being male is entwined with and complicated by other categories of being - all of which are being tied to structures of power. What the avenue we have opened speaks to then are interconnected elements of individual deliberate activity and "thrownness", the entanglement of the things that individuals can do something about and those that they can do very little about, that have to be recognised in analyzing male 
practices and experiences. Most of all, it speaks of a person's power and powerless in the face of social structures and their own lives.

Turning away from the individual and towards the political, approaching males at the level of groups, studies show that currently African countries have a predominance of young people (African Union Commission (AU), 2006). Over 1 in every 2 Africans is below the age of 20. In some countries, the population under 15 years is as high as $47 \%$ and $50 \%$, Angola and Uganda being cases in point. But there are countries where figures for those under 15 years of age are a more reasonable $27 \%$ and $24 \%$ of the population; the examples in this regard are Tunisia and Mauritius. For the whole continent, the population under 15 is $42 \%$ and those of 65 is only $3 \%$, and females comprise $52 \%$ of this young population (see Table 1 ).

\section{Table 1}

Population of under-15s and 65+ for selected African countries

\begin{tabular}{lccc}
\hline & $\begin{array}{c}\text { Population } \\
\text { age }<\mathbf{1 5}(\mathbf{\%})\end{array}$ & $\begin{array}{c}\text { Population } \\
\text { age } \mathbf{6 5 +}(\mathbf{\%})\end{array}$ & $\begin{array}{c}\text { Population } \\
\text { mid-2006 } \\
\text { (millions) }\end{array}$ \\
\hline Uganda & 50 & 3 & 27.7 \\
Angola & 47 & 3 & 15.8 \\
Chad & 47 & 3 & 10.0 \\
Burkina Faso & 46 & 3 & 13.6 \\
Zambia & 45 & 3 & 11.9 \\
Benin & 44 & 3 & 8.7 \\
Equatorial Guinea & 44 & 4 & 0.5 \\
Sudan & 44 & 2 & 41.2 \\
Tanzania & 44 & 4 & 37.9 \\
Gabon & 40 & 4 & 1.4 \\
Cape Verde & 38 & 6 & 0.5 \\
Egypt & 35 & 5 & 75.4 \\
Algeria & 31 & 5 & 33.5 \\
Tunisia & 27 & 7 & 10.1 \\
Mauritius & 24 & $\mathbf{3}$ & 1.3 \\
Africa as a whole & $\mathbf{4 2}$ & & $\mathbf{9 2 4}$ \\
\hline Source AU, & & 7 &
\end{tabular}

(Source: AU, 2006). 
The predominance of young people might suggest that the young - both young women and men - should have a voice in how their continent is governed. Indeed it could be said that given their numbers, if nothing else, they themselves should be in decision-making positions in politics and society. This is not the case though. The reality is that young people are on the whole politically powerless. This powerlessness reveals and reinforces certain important aspects of the workings of power. ${ }^{1}$ Although there are more people under20 years of age than there are those over- 50 years in age in many countries (AU, 2006), yet there is likely to be an over-representation of over-50s and no under-20s in political office. This indicates that while numbers can translate to majority rule, the domination of society by a minority of older males evidences that their power is drawn from elsewhere. Even though in cases where they are enfranchised the majority can use their democratic rights to change a conservative or bad government for a progressive one, it is clear that is not in numbers only that power resides. And while age qualifies one for certain rights, there is more to the domination of the older members of a society over younger members. In short, the domination of countries by a minority of older males is due to their active structuring of society in their own favour (see Barker and Ricardo, 2005).

It could be asked why young people do not "fight the power" that prevents them from voting, or from changing the laws and policies that exclude their voices from decision-making structures. It is not that there have not been social revolutions led by students and youth in Europe, the US and African countries. Young people have also been, and continue to be involved, in armed conflicts in many parts of Africa. In fact, Barker and Ricardo maintain that "many (armed insurgencies) are directly related to an attempt by young men to acquire power, or to question the power of specific groups of older men, and to live up to a specific version of manhood (2005: 24-25). If young men can take up arms to "act out a socially recognized role of manhood taken to its extreme" and sometimes even seek to "question the power of specific groups of older men”, (Barker \& Ricardo, 2005: 25) why can they not work within gender movements against age-based male power, especially in societies where young people are a significant majority of the population and are patently powerless?

The answer is that there are virtually no youth movements that overtly struggle against age-based male power. And the reason that there have not been more large-scale socio-political revolutions led by young women and

${ }^{1}$ Of course, a similar lesson is observable in the way settler minorities and small populations of whites in many African countries yoked together different forms of power, including violence legitimized in law, to oppress large numbers of Africans and other populations in those countries. 
men in Africa or the rest of world is that where mass socio-political mobilization started to take root men in power have crushed it, often brutally. Consider in this respect what happened in 1976, in Soweto, South Africa. Students rose up against the apartheid regime's imposition of Afrikaans, the "language of the oppressing tribe", as the medium of instruction in black schools. The state's response was swift, ruthless; many young people were fatally shot by soldiers, some while running away, others were thrown in jail, while others fled into exile.

On the other hand, young people have been pressed into supporting conflicts around them, conflicts which have nothing to do with their economic, social or psychological interests and serve "strong" men or those contesting for power; or because unfavourable conditions have seduced them to join the war or political gangs in their countries. "Many of us, especially the boys, are forced to join various armed groups," young people from conflict zones attest in 'Will you listen?' (UNPFA/UNICEF/Women's Commission for Refugee Children and Women, 2007: 4).

They then put us in the front of the battlefields or force us to spy on the opposition. They brainwash us into believing that we are fighting to defend our rights and our communities. Even the girls are put through this. As soldiers, we are sometimes given strong drugs and put through grotesque rituals to make us "strong" and not afraid. Some of us who have lost our parents and live in the streets are tempted to join the militia. At least they will take care of us (2007: 4).

What is clear about struggles such as those waged by young people in South Africa to overturn a racially noxious regime, as well as conflicts which young people are forced to join such as those in Rwanda and Uganda, is that they have nothing to do with the desire to challenge male domination, that, indeed, ruling men do press the age factor with the help of social structures to support masculine domination. Clearly, there is a need for more studies to understand young people's lives and experiences from the vantage point of gender (Pattman \& Chege, 2003).

The conclusion we can draw from reading manhood together with age is how a version of masculinity a particular African male might get to support could be based on fabrication as much as on actual socio-economic and political facts. Masculinity is thus as much about what is dreamed of as what is, in differing degrees. Given the limits and opportunities granted by age, then, the experience and practice of masculinity of males is more often than admitted, tenuous, internally contradictory and, as it were, all performance and nothing (see Barker \& Ricardo, 2005). 


\section{The Burdens of Masculinity and Occupational and Income Attainment}

Gainful employment is about more than just about money. Ultimately occupational attainment and income afford a person choices, including the choice on how to participate in the world, eating what one desires rather than what is available, and living in conditions of one's choosing (see African National Congress, 1994; Statistics South Africa, 2001; Townsend, 1979; United Nations Development Programme South Africa, 2003; for a discussion of the flip-side of this argument, on poverty). As Barker (2005: 102) remarks "work and producing income" are "key requisites for being a man in most cultures". What this suggests is that critical engagement with masculinities needs to aim at making available more choices to females - given that traditionally males tended to have more life choices than females - and to subordinated males. This would mean taking seriously the fact of gainful occupation.

The fact though is that in most African countries opportunities to fulfil the burdens of masculinity are slim; unemployment levels in the formal labour sector are high; salaries for the majority of people are below the poverty line. On this basis we can hypothesise a link between levels of both instrumental and expressive male violence, and levels of unemployment, specifically unemployment in contexts of great income inequality, such as in South Africa. This link is directly and indirectly supported by studies from South Africa which has high levels of unemployment and high levels of male violence (e.g., see Centre for the Study of Violence and Reconciliation, 1998; Crime Information Analysis Centre: South African Police Service, 2007; Prinsloo, 2007; Schönteich \& Louw, 2001; Statistics South Africa, 2005).

To state that gainful employment is more than just about money is to indicate that employment and income go toward satisfying ego needs as they also satisfy material ones. At the same time, salaried employment and wealth may be used to perpetuate the subordination of women to men, and often are. Having a job, earning a salary, or "getting" money by other means, it has been argued, may even be "the chief socially recognized functions" for adult males and "key components of men's identities" (Barker, 2005, p.104). In her work on the emergence of the "breadwinner ideal" in colonial southwestern Nigeria, Lindsay (2007) maintains that while she agrees with studies that argue that this (breadwinner) ideal arrived in Nigeria with colonialism, "Nigerian working husbands and wives were active agents in the process, in a context in which the colonial state also operated with mixed motives" (242). She contends that given a colonial state that discriminated in favour of European males as far as wages were concerned, the agency of Nigerians in the production of the image of the men as breadwinners entailed explaining to employers 
that the earnings of married men were critical in supporting their families (similar to European males whom the colonial authorities paid more because it was said they were breadwinners). Of interest here is that the explanation proffered by representatives of Nigerian workers paradoxically ignored the activities of women which brought in incomes, such as trading at the market, or else these activities were defined as less important than male's remunerative work.

It seems clear that money is not only about masculine power and identity, but makes possible other choices, rendering life as less harsh, as well as organising society, shaping institutions. The same holds for countries: richer countries are on average able to offer more chances of employment, better quality of life, and reduced chances of dying a young and brutal death to their citizens - at least to the affluent amongst their citizens. It is also clear that on average in richer countries struggles between women and men change their form: physical violence (or at least reports of physical violence) is less evident than emotional and economic abuse (which tends not to be reported to the same extent to the police) (Krug et al., 2002).

The African Union Commission (2006) is aware of the multiple functions of employment and money when it states that all the Millennium Development Goals are tied up in direct or indirect ways with gender quality and the empowerment of women. For example, as the participation of women in a country's economic and political life increase, so does the control over their own lives increase. This control over one's life includes being able to make choices about their sexual desires, contraception, number of and space between children they want to have, their own health and that of their children, and the use of money. The problem is that the participation of women in the labour force in many countries continues to lag behind that of men. Figure 1 (AU, 2006) illustrates this gendered difference in employment in selected countries by showing the share of women's share of nonagricultural occupations, which is reported to be about $20 \%$ in many African countries.

The AU Commission (2006) also draws attention to the fact that employment and income problems facing African women and men are severe, multidimensional, and higher than in other regions of the world, with "half of Africans living in extreme poverty and one third in hunger" (16). Tables 2 and 3 support this, showing the officially reported rates of unemployment in different regions of Africa in 2003. However, what the tables conceal is how many of those who are unemployed and live in poverty are females (or live in female-headed households) and how many are males (or live in male-headed households). Critical analyses of gender power always need to be suspicious of such a lack of disaggregation of data. 


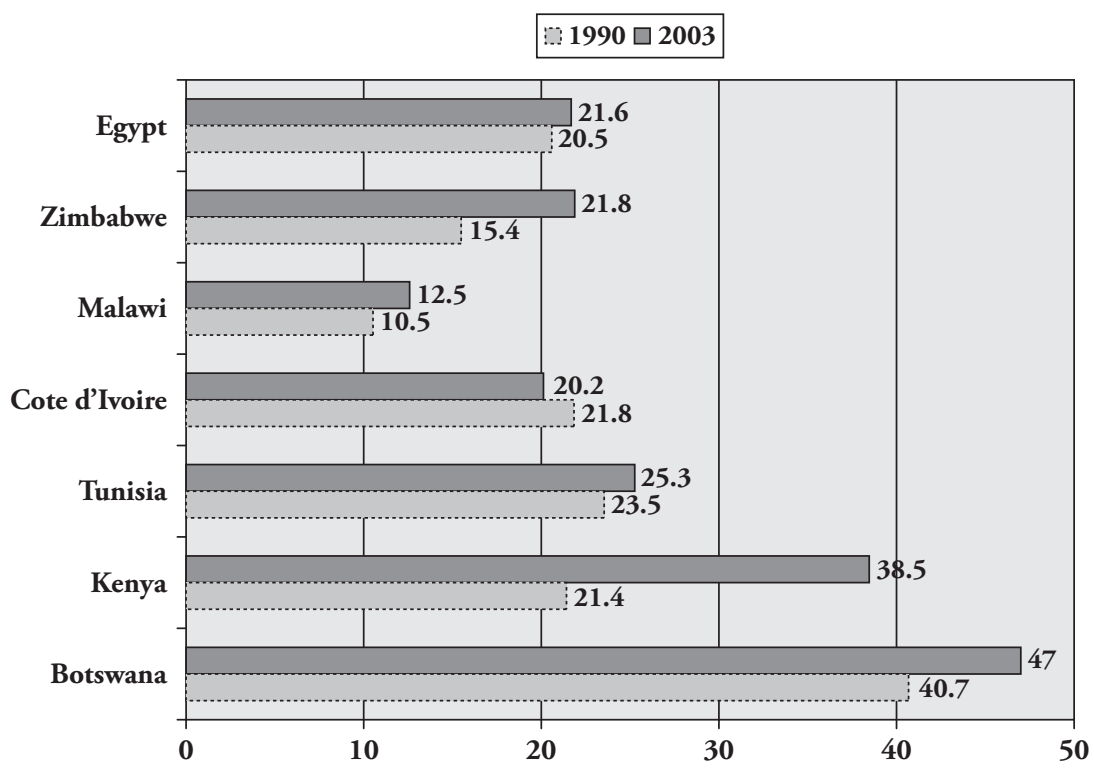

Figure 1

Women's share of non-agricultural occupation, 1990 and 2003

Table 2

Variations in unemployment rates across regions, 2003 (\%)

\section{Region}

Unemployment rate

Western Africa

6.7

Central Africa

9.4

Northern Africa

10.4

Eastern Africa

Southern Africa

(Source: UNECA cited in the AUC, 2006)

Even then, these unemployment statistics may well understate the situation. As the AU Commission maintains,

The collection of employment data in Africa is fraught with difficulty. Many countries do not report correct inform ation, reporting countries given incomplete data, and not all reported information is comparable across countries. Moreover, the average unemployment figures do not capture discouraged job seekers. The limited demand (sic) for formal jobs in Africa discourages large numbers of potential workers form seeking employment; by definition they are not counted as unemployed $(2006,18)$. 


\section{Table 3}

Variations in country rates

\begin{tabular}{lccc}
\hline Country & Year & Unemployment rate (\%) & Working age \\
\hline Zimbabwe & 1999 & 6 & $15+$ \\
Uganda & 1997 & 7 & $7+$ \\
Egypt & 2000 & 9 & $15-64$ \\
Zambia & 1996 & 15 & $12+$ \\
Botswana & 2000 & 16 & $12+$ \\
Kenya & 1994 & 21 & $15+$ \\
South Africa & 2001 & 30 & $15-65$ \\
Namibia & 2000 & 34 & $15-69$ \\
Lesotho & 1997 & 39 & $15+$ \\
\hline
\end{tabular}

[Source: International Labour Organisation (2005) cited in the AUC (2006)]

It is important to note that there are a number of factors that underlie problems around the attainment of adequate employment and income in many African countries besides gender inequality. Some of these factors are internal to countries and others are external (AUC, 2006). Internal factors include the marginalization of youth, high burden of morbidity and mortality, low levels of education, low levels of investment in human capital and political instability. External factors include the high indebtedness of some countries, unfavourable terms of trade with rich countries, unfair pricing of raw materials that most African economies depend on, and inaccessible markets of the rich countries. When this combination of factors interacts with gender factors, the economic situation of women tends to be aggravated while they also result in complex consequences for men and masculinities, (such as involvement in gangs or inter-personal violence, leaving their families or partners, engagement in extra-legal activities for the sake of money, and sexual relations with other women than their regular partner to refurbish their dented manhood) (see Barker, 2005).

While there may still be men who are informed by an ethic of working hard for the sake of work, many men will work so that they can climb the economic value ladder. The way up could be through their trade, profession, business, sports or another route. However, owing to the fact that some of the routes towards success may be closed to some men, either because of widespread joblessness, lack of training or education, war, racially or ethnically biased policies, or changes in industry, extra-legal means to achieve successful man- 
hood are not excluded. In many African countries, the realities are that weak economies, high levels of unemployment, and deep inequalities mean that criminal economic activity, including pervasive corruption, become part of the experiences and practices of men who feel disabled from achieving successful manhood by their lack of good employment prospects.

\section{Conclusion}

The aim of this article was to offer an analysis on how and why males have been, and need to be, studied from the perspective of gender in Africa. Masculinities, the article sought to show, is better viewed as produced at both the social and psychological levels, and that viewed thus, male experiences and practices disperse and internally fragment the notion of African masculinity. The paper has suggested that more changes to the gendered African worlds and masculinity are possible if interventions into male lives observe the intersections between, for instance, the social-psychological experience of being an African male and the experience of being young or unemployed. Such intersections reveal how male groups are diverse and African masculinities dispersed, heterogeneous and fluid. And, as consequence of this recognition of the fragmented, diverse and changing character of African masculinities, we are able to mount better interventions against ruling ideas of being a man or boy, including interventions against the daily wars around gender.

\section{References}

Adomako Ampofo, Akosua and Boateng, John. 2007. "Multiple meanings of manhood among boys in Ghana," In From boys to men: social construction of masculinity in contemporary society. Landsdowne: University of Cape Town Press.

African National Congress. 1994. Reconstruction and development programme: a policy framework. Johannesburg: Umanyano Publications.

Agenda, 1998. The new man? 37 (7).

African Union Commission (AU). 2006. The state of the African population 2006: population dynamics: implications for achieving the Millennium Development Goals. African Union.

Altbeker, Anthony. 2007. A country at war with itself: South Africa's crisis of crime. Johannesburg: Jonathan Ball Publishers.

Barker, T. Gary. 2005. Dying to be men: youth, masculinity and social exclusion. London: Routledge. Barker, Gary. \& Ricardo, Christine. 2005. Young men and the construction of masculinity in subsaharan Africa: implications for HIVIAIDS, conflict, and violence. Social Development Papers: Conflict Prevention \& Reconstruction, Paper No. 26 / June. Conflict Prevention \& Reconstruction Social Development Department, The World Bank, Washington, DC. Available from http://www.worldbank.org/conflict.

Biko, Stephen.1978. I write what I like. London: Bowerdean.

Blackbeard, David and Lindegger, Graham. 2007. “'Building a wall around themselves': exploring adolescent masculinity and abjection with photo-biographical research," South African Journal of Psychology, 37(1): 25-46. 
Bly, Robert. 1990. Iron John: a book about men. Shaftesbury, Dorset: Element.

Breckenridge, Keith.1998. "The allure of violence: men, race and masculinity on the South African Goldmines, 1900-1950.” Journal of Southern African Studies, 24 (4) (Special Issue on Masculinities in Southern Africa): 669-693.

Brod, Harry. ed. 1987. The making of masculinities: the new men's studies. London: Allen and Unwin.

Carrigan, Tim, Connell, W. Robert and Lee, John. 1985. "Toward a new sociology of masculinity," Theory and Society, 14 (5): 551-604.

Castells, Manuel. 2000. The rise of the network society (2nd ed). Blackwell Publishers. Oxford.

Chabani, N.C. 1973. Being-black-in-the-world. Johannesburg: Ravan.

Chabani, Noel Chabani.1981. Looking through the keyhole. Johannesburg: Ravan.

Clatterbaugh, Kenneth. 1998. "What is the problematic about masculinities?" Men and Masculinities 1(1): 24-45.

Connell, W. Robert. 1995. Masculinities. Cambridge: Polity Press.

Connell, W. Robert and Messerschmidt, W. James. 2005. "Hegemonic masculinity: rethinking the concept." Gender Society, 19: 829-895.

Centre for the Study of Violence and Reconciliation. 1998. Into the heart of darkness: journeys of the amagents in crime, violence and death. Paper prepared as part of research conducted by the Centre for the Study of Violence and Reconciliation for the Council for Scientific and Industrial Research. Available from http://www.csvr.org.za/index.php?option=comcontent\&task=v iew\&id=533.

Crime Information Analysis Centre: South African Police Service. Crime situation in South Africa, April-September 2007: trends, spatial distribution and interpretation, 2007. Available from http://www.saps.gov.za/statistics/reports/crimestats/2007/_pdf/crime_situation1.pdf.

Dobson, James. 2002. Bringing up boys: practical advice and encouragement for those shaping the next generation of men. Vereeniging: Christian Art Publishers, 2002.

Dolan, Chris. 2002. "Collapsing masculinities and weak states: case study of Northern Uganda." In Masculinities Matter! Men, Gender and Development. London: Zed Books.

Fanon, Frantz. 1986. Black Skin, White Masks. London: Pluto.

- 1990. The wretched of the earth. London: Penguin.

Field, Sean. "Disappointed Men." 2001. In Changing Men in Southern Africa. Pietermartizburg: University of Natal Press, and London: Zed Books.

Fouten, S. Elron. 2006. "Exploring how adolescent boys negotiate regulatory conceptions of masculinity.” Unpublished M.A. Psychology (Research) thesis, University of Western Cape, Bellville.

Gibson, Diana and Hardan, Anita. 2005. eds. Rethinking masculinities, violence and Aids. Amsterdam: Het Spinhuis.

Gqola, Pumla Dineo. 2007. “'A woman cannot marry a boy': rescue, spectacle and transitional Xhosa masculinities.” In From Boys to Men: Social Construction of Masculinity in Contemporary society. Landsdowne: University of Cape Town Press.

Hearn, Jeff. 1987. The gender of oppression: men, masculinity and the critique of Marxism. Sussex: Wheatsheaf Books.

- 1996. "Is masculinity dead? A critique of the concept of masculinity/masculinities." In Understanding masculinity. Buckingham: Open University Press.

Hook, Derek. 2004. "Frantz Fanon, Steve Biko, 'psychopolitics' and critical psychology." In Critical Psychology. Landsdowne. University of Cape Town Press.

Hunter, Mark. 2005. "Cultural politics and masculinities: multiple-partners in historical perspective." In Men behaving differently: South African men since 1994. Cape Town, South Africa: Double Storey.

IRIN/UN Office for the Coordination of Humanitarian Affairs. Swaziland: Women challenging their traditional status as minors. 8 March 2005. - [cited 8 July 2008]. Available from http:// www.irinnews.org/report.aspx? reportid $=53331$ 
Jewkes, Rachel, Dunkle, Kristin, Koss, P. Mary, Levin, B. Jonathan, Nduna, Mzikazi, Jama, Nwabisa and Sikweyiya, Yandisa. 2006. "Rape perpetration by young, rural South African men: Prevalence, patterns and risk factors," Social Science \& Medicine 63: 2949-2961.

Journal of Southern African Studies. 1998. Special Issue on masculinities. 24(4).

Kimmel, S. Michael, Hearn, Jeff, and Connell, W. Robert. 2005. Handbook of studies on men and masculinities. London: Sage.

Kimmel, S. Michael. 1994. "Masculinity as homophobia: fear, shame, and silence in the construction of gender identity". In Theorizing masculinities. Thousand Oaks, CA: Sage.

- ed. 1987. Changing men: New directions in research on men and masculinity. London: Sage Publications.

Krug, G. Etienne, Dahlberg, L. Linda, Mercy, A. James, Zwi, B. Anthony and Lozano, Rafael. 2002. eds. World report on violence and health. Geneva: World Health Organization.

Langa, Malose and Eagle, Gillian. 2008. "The intractability of militarised masculinity: A case study of former Self-Defence Unit members in the Kathorus area, South Africa." South African Journal of Psychology, 38(1): 152-175.

Lindsay, A. Lisa. 2007. "Working with gender: the emergence of the 'male breadwinner' in colonial southwestern Nigeria," In Africa after gender?. Bloomington: Indiana University Press.

Lindsay, A. Lisa, and Miescher, F. Stephan. 2003. Men and masculinities in modern Africa. Portsmouth, NH. Heinemann.

Manganyi, N. Chabani.1991. Treachery and innocence: psychology and racial difference in South Africa. Braamfontein: Ravan.

- 1973. Being-black-in-the-world. Johannesburg: Spro-Cas/Ravan.

Miescher, F. Stephan. 2007. "Becoming an $\bigotimes$ Hispanyin: elders, gender, and masculinities in Ghana since the nineteenth century," In Africa after gender? Bloomington: Indiana University Press.

Morrell, Robert. ed. 2001. Changing men in Southern Africa. Durban: University of Natal Press.

Mac an Ghaill, M. ed. 1996. Understanding masculinities: social relations and cultural arenas. Buckingham: Open University Press.

Nilan, P., Donaldson, M. and Howson, 2007. R. "Indonesian Muslim masculinities in Australia." Asian Social Science, 3(9): 18-27.

Ouzgane, Lahoucine and Morrell, Robert. Eds. 2005. African masculinities: men in Africa from the late nineteenth century to the present. New York: Palgrave Macmillan.

Parker, Zarina, Dawes, Andy and Farr, Valerie. 2004. "Interpersonal youth violence prevention," In Crime, Violence and Injury prevention in South Africa: Developments and Challenges. Tygerberg: Medical Research Council-University of South Africa Crime, Violence and Injury Lead Programme.

Pattman, R, \& Chege, F. 2003. Finding our voices: Gendered \& sexual identities and HIVIAIDS in education. Nairobi: UNICEF.

Prinsloo, Megan. 2007. Ed. A profile of fatal injuries in South Africa: 7th Annual Report of the National Injury Mortality Surveillance System, 2005. Medical Research Council/University of South Africa Crime, Violence and Injury Lead Programme.

Ratele, Kopano. 2006. Ruling masculinity and sexualities. Feminist Africa 6 (Subaltern sexualities): 48-64.

Ratele, Kopano, Fouten, Elron, Shefer, Tammy, Strebel, Anna, Shabalala, N. Joy and Buikema, Rosemarie. 2007. "'Moffies, jock and cool guys'. Boys' accounts of masculinity and their resistance in context," In From boys to men: social construction of masculinity in contemporary society. Landsdowne: University of Cape Town Press.

Reid, Graeme and Walker, Liz. eds. 2005. Men behaving differently: South African men since 1994. Cape Town, South Africa: Double Storey.

Ruxton, S. ed. 2004. Gender equality and men: learning from experience. Oxford: OXFAM. 
SAPA. 2008. "Outrage over attack on miniskirt-wearing woman." Mail\&Guardian online, 19 February 2008 - [cited 8 July 2008]. Available from http://www.mg.co.za/article/200802-19-outrage-over-attack-on-miniskirtwearing-woman.

Schönteich, M. and Louw, 2001. A. Crime in South Africa: a country and cities profile. Institute for Security Studies, Occasional Paper No 49.

Shefer, Tammy, Ratele, Kopano, Strebel, Anna, Shabalala N. Joy and Buikema, Rosemarie, eds. 2007 From boys to men: social construction of masculinity in contemporary society. Landsdowne: University of Cape Town Press.

Sideris, Tina. 2005. "You have to change and you don't know how!' contesting what it means to be a man in a rural area of South Africa". In Men behaving differently: South African men since 1994. Cape Town, South Africa: Double Storey.

Statistics South Africa. 2005. Labour Force Survey September 2005. Pretoria: Statistics South Africa.

Townsend, P. 1979. Poverty in the United Kingdom. Harmondsworth, Middlesex: Penguin Books.

Wetherell, Margaret and Edley, Nigel. 1999. "Negotiating hegemonic masculinity: imaginary positions and psycho-discursive practices.' Feminism and Psychology, 9(3): 335-356.

Women's Commission for Refugee Women and Children. 2005. Masculinities: Male Roles and Male Involvement in the Promotion of Gender Equality: A Resource Packet. Women's Commission for Refugee Women and Children. New York. Available from wcrwc@womenscommission.org.

Women's News Network. 2007. "The first casualties in wartime happen to be women.” Daily Star, 02 Jun 2008 - [cited 8 July 2008]. Available from http://www.worldywca.info/index. php/ywca/women_s_news/articles/the_first_casualties in_wartime_happen_to_be_women.

United Nations Development Programme South Africa. 2003. South Africa Human Development Report 2003 - the challenge of sustainable development: unlocking people's creativity. Cape Town: Oxford University Press. Available from http://www.undp.org.za/NHDRF.htm.

United Nations Division for the Advancement of Women/Joint United Nations Programme on HIV/Aids/ International Labour Organisation/United Nations Development Programme. 2004. The role of men and boys in achieving gender equality: report on the expert group meeting, Brasilia, Brazil, 21-24 October 2003. New York: Division for the Advancement of Women, Department of Economic and Social Affairs.

United Nations International Research and Training Institute for the Advancement of Women (INSTRAW). Ending men's violence. United Nations INSTRAW, no date. Available from http://www.un-instraw.org/en/index.php?option=content\&task=view\&id=909\&Itemid=0.

United Nations Population Fund (UNFPA)/ United Nations Children's Fund (UNICEF)/ Women's Commission for Refugee Children and Women. Will you listen? Young voices from conflict zones, 2007. Available from http://www.unfpa.org/upload/lib_pub_file/720_filename_will_you_listen_090607.pdf.

United Nations Population Fund (UNFPA). State of World Population 2005: The Promise of Equality Gender Equity, Reproductive Health and the Millennium Development Goals, 2005. UNFPA. Available online at http://www.unfpa.org/swp/2005/pdf/en_swp05.pdf.

Vijayan, P. "Nationalism, masculinity and the developmental state." In Masculinities matter! men, gender and development. London: Zed Books, 2002.

Wood, Katherine and Jewkes, Rachel. "Dangerous love": reflections on violence among Xhosa township youth." In Changing Men in Southern Africa. University of Natal Press/Zed Books, 2001. 